\title{
SOCIETAL INITIATIVES - A STUDY OF LEGAL COMPLIANCE OF CSR BY SELECTED MAHARATNA COMPANIES OF INDIA
}

\author{
Senior Research Fellow, \\ S.D. School of Commerce, \\ Gujarat University-380009 \\ Associate Professor, \\ S.D. School of Commerce, \\ Gujarat University-380009
}

Pragnesh B. Dalwadi, Dr. Gurudutta P. Japee

\begin{abstract}
The main purpose of this study is to know the CSR compliance obeyed by public sector enterprises in India. The data have been gathered from annual reports of the chosen five Maharatna Companies of India. The data of average profit prescribed CSR, and amount spent on CSR of company-wise have been tabulated and analyzed using descriptive statistics and ANOVA. The study has been found that GAIL has maintained consistency in the amount spent for CSR, while the other selected Maharatna companies showing high variance during the period of study. Amongst these five, PGC has shown a tremendous increasing trend while the rest are showing decline or fluctuation in the amount spent on social and environmental wellbeing. This study also found that excess amount over and above mandatory requirement has been spent by SAIL, GAIL, and NTPC while BHEL and PGC show deficit in the amount spent which shows that still, these two companies haven't spent full amount as per Companies Act for CSR.
\end{abstract}

Keywords: Corporate Social Responsibility (CSR), Societal Initiatives, Maharatna companies, mandatory requirements, and the amount spent.

\section{INTRODUCTION}

Corporate Social Responsibility (CSR) is what businesses are giving back to society. They enjoy the utilization of natural resources like land, water, and environmental harm, biodiversity, etc. CSR is that the collective responsibility of companies to revive an honest atmosphere to the health of society. While profit maximization is that the primary objective of the company sector, CSR activities are likely to counterpoint the environment (Shanmugam \& D S, 2019). The idea of CSR isn't a contemporary concept; it began many centuries ago. In ancient India, kings made contributions to the expansion of society. for instance, King Harshavardhan, who ruled North India during the Sixth Century, maybe an ideal (Shanmugam \& D S, 2019). The essence of the societal interventions may eventually depend upon the firm's perceptions of certain structural constraints and perceptions of the link between the firm and also the firm's future competitive advantages and identity as a "responsible firm. Societal initiatives can have dramatically different impacts on a society looking at the number of resources committed to the project and its integration with the project (Dalwadi \& Sharma, 2019). The CSR scenario is evolving rapidly in India. The creation of the new companies act of 2013 and also the stipulation of the latest guidelines by SEBI gave the operations of the CSR and its reporting a brand new facelift by making it compulsory instead of voluntary.

(Parliament, 2013) Activities which may be included by companies in their Corporate Social Responsibility Policies Activities relating to:-

(i) Eradicating extreme hunger and poverty;

(ii) Promotion of education;

(iii) Promoting gender equality and empowering women;

(iv) Reducing child mortality and improving maternal health;

(v) Combating human immunodeficiency virus, acquired immune deficiency syndrome, malaria, and other diseases;

(vi) Ensuring environmental sustainability;

(vii) Employment enhancing vocational skills;

(viii) Social business projects;

(ix) contribution to the Prime Minister's National Relief Fund or any other fund set up by the Central Government or the State Governments for socio-economic development and relief and funds for the welfare of 


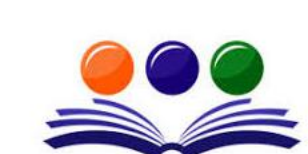

GRAND ACADEMIC PORTAL RESEARCH JOURNALS
GAP INTERDISCIPLINARITIES A Global Journal of Interdisciplinary Studies

( ISSN - 2581-5628)

Impact Factor: SJIF - 5.047, IIFS - 4.875

Globally peer-reviewed and open access journal,

the Scheduled Castes, the Scheduled Tribes, other backward classes, minorities and women; and (x) Such other matters as may be prescribed.

\section{REVIEW OF LITERATURE}

Kapoor \& Saluja (2014) claimed that the idea of Corporate Social Responsibility (CSR) has not been new in India. It originated from the Vedic period when history in India was not recorded. The Kings had a duty to society at that time and the merchants demonstrated their business duty by building places of worship, education, inns, and wells. They discussed the fact that, over the last four decades, corporate social responsibility has been developed and conceptualized in several ways following a process.

Sarkar \& Sarkar (2015) analyzed the potential implications for firm rewards of mandated CSR under the Companies Act 2013 in India, the likely responses of law enforcement firms, the consequences for the availability of services and the distribution of social goods, and the prospects and challenges for the implementation of mandated CSR. The voluntary CSR activities of a sample of 500 large companies listed on the Bombay Stock Exchange for the period 2003-2011, predating the new legislation, were evaluated empirically. They submitted that the provisions of the new act are carefully structured to balance the corporate goals and its members, on the one hand, and the corporation and its stakeholders' goals, on the other, with the potential economic costs which will follow the mandated CSR. However, the effective overcoming of implementing issues will assess the level of achievement of the objectives of the new regulations.

Mukherjee \& Bird (2016) examined drivers and impediments to the expenditure of CSR; it evaluated the attitude of Indian companies to CSR activities and the impact of mandatory CSR expenditure. They analyzed 223 companies and found that companies' attitudes to CSR expenditure vary widely in terms of age, scale, and ownership. They also discovered that the requirement to make CSR costs compulsory to large companies did not lead to the expected expenditure rise because it was avoided by many companies that were compulsory, and their expenditures decreased with the large number for which it was not compulsory.

Venugopal \& Krishnan (2018) analyzed the impression of the employees and beneficiaries on the major issues which the Bank considers should be addressed on a priority basis in CSR initiatives. They found that the employee's employments of Differently Abled was regarded as the one with the highest priority and that the beneficiaries considered promotion of education, child welfare, and female employment as the three most important issues.

Dalwadi \& Sharma (2019) concluded that during this study period the growth in the social initiative has reached a low peak, while the amounts spent on social initiatives between districts have been unequal, while businesses focus more on education and health in the limited districts. It also noticed that the establishment of underdeveloped and developing state regions should be worked together by companies and the government.

\section{OBJECTIVES OF THE STUDY}

1. To study the CSR practices of selected Maharatna companies of India

2. To analyse whether the chosen Maharatna companies comply with the Companies Act. 2013 concerning the sums spent on CSR purposes.

\section{METHODOLOGY OF THE STUDY}

The main objective of the study is to know the CSR compliance by public enterprises. Through the purposive sampling method total of five Maharatna companies have been selected and a descriptive research design has been used to meet the objective. The data have been collected from secondary sources from the annual reports of the respective company for the period ranging from 2014-15 to 2018-19.

Mainly the data of average profit, CSR prescribed, and the actual amount spent on CSR has been tabulated for better understanding. The collected data has been analyzed using descriptive statistics and ANOVA. This study is constrained to a specific time and specific place. It can be possible that the result may differ from time and place. There is a certain limitation of the methods and tools used in this study; the same applies to this study.

\section{Hypothesis}

Null Hypothesis

$\mathbf{H}_{0}$ : All the selected companies have an equal amount spent on corporate social responsibility during the study period

Ho: All the selected companies have an equal surplus or deficit amount spent compared to legal requirements

\section{Alternative Hypothesis}

$\mathbf{H}_{1}$ : All the selected companies have unequal amount spent on corporate social responsibility during the study period 


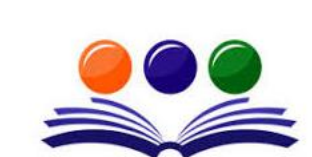

GRAND ACADEMIC PORTAL RESEARCH JOURNALS
GAP INTERDISCIPLINARITIES A Global Journal of Interdisciplinary Studies

( ISSN - 2581-5628)

Impact Factor: SJIF - 5.047, IIFS - 4.875

Globally peer-reviewed and open access journal.

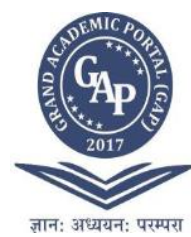

Table No: 5.3: Amount of profit and spent on CSR purpose GAS AUTHORITY OF INDIA LIMITED (GAIL) (₹ in crore)

\begin{tabular}{|c|c|c|c|c|}
\hline Year & $\begin{array}{l}\text { Average profit } \\
\text { (Considered profit before tax of last } \\
\text { three years) }\end{array}$ & $\begin{array}{l}\text { Prescribed CSR expenditure }(2 \% \text { of the } \\
\text { average profit) } \\
\text { (a) }\end{array}$ & $\begin{array}{l}\text { Actual } \\
\text { amount } \\
\text { spent } \\
\text { (b) }\end{array}$ & $\begin{array}{l}\text { Unspent(-) } \\
\text { /Overspent( }(+) \\
\text { (in rupees) } \\
\text { (b-a) }\end{array}$ \\
\hline $\begin{array}{l}2014- \\
15\end{array}$ & $5,933.37$ & 118.6 & 118.06 & $(0.54)$ \\
\hline $\begin{array}{l}2015- \\
16\end{array}$ & $5,117.05$ & 102.34 & 160.56 & 58.22 \\
\hline $\begin{array}{l}2016- \\
17\end{array}$ & 4,074 & 81.48 & 123.58 & 42.1 \\
\hline $\begin{array}{l}2017- \\
18\end{array}$ & $3,483.50$ & 69.67 & 91.65 & 21.98 \\
\hline $\begin{array}{l}2018- \\
19\end{array}$ & $4,360.64$ & 87.21 & 119.29 & 32.08 \\
\hline Total & $22,968.56$ & 459.3712 & 613.14 & 153.7688 \\
\hline Mean & $4,593.712$ & 91.86 & 122.628 & 30.768 \\
\hline S.D. & 952.045 & 19.017 & 24.655 & 22.029 \\
\hline C.V & $20.72 \%$ & $20.70 \%$ & $20.11 \%$ & $71.60 \%$ \\
\hline
\end{tabular}

The table above displays the data carried out by GAIL Company during the period from 2014-15 to 2018-19 relating to corporate social responsibility. The above table indicates that the organization has spent more than the prescribed amount on CSR last year, which illustrates the company's awareness about social responsibility.

Table No.5.4: Amount of profit and spent on CSR purpose

\begin{tabular}{|c|c|c|c|c|}
\hline Year & $\begin{array}{l}\text { Average profit } \\
\text { (Considered profit before tax } \\
\text { of last three years) }\end{array}$ & $\begin{array}{l}\text { Prescribed CSR } \\
\text { expenditure }(2 \% \text { of } \\
\text { the average profit) } \\
\text { (a) }\end{array}$ & $\begin{array}{l}\text { Actual } \\
\text { Amount } \\
\text { spent } \\
\text { (b) }\end{array}$ & $\begin{array}{l}\text { Unspent(-) } \\
\text { /Overspent(+) } \\
\text { (in rupees) } \\
\text { (b-a) }\end{array}$ \\
\hline $2014-' 15$ & $14,173.78$ & 283.48 & 205.18 & $(78.3)$ \\
\hline $2015-16$ & $13,567.43$ & 271.35 & 491.80 & 220.45 \\
\hline $2016-' 17$ & $11,392.68$ & 227.85 & 277.81 & 49.96 \\
\hline $2017-' 18$ & $11,037.30$ & 220.75 & 241.54 & 20.79 \\
\hline $2018-19$ & $11,850.34$ & 237.01 & 285.46 & 48.45 \\
\hline Total & $62,021.53$ & $1,240.44$ & $1,501.79$ & 261.35 \\
\hline Mean & $12,404.31$ & 248.09 & 300.36 & 52.27 \\
\hline S.D. & $1,385.899$ & 27.719 & 111.690 & 107.638 \\
\hline C.V & $11.17 \%$ & $11.17 \%$ & $37.19 \%$ & $205.93 \%$ \\
\hline
\end{tabular}

Source: - Annual Report

The table above illustrates that the business invested a lot less on CSR than prescribed in 2014-15, but subsequently made excellent advances and spent more on CSR than the remainder of the year between 2015-16 and 2018-19. In general, the Company has spent more on CSR than necessary, which demonstrates the organization's emphasis on social responsibility.

Table No.5.5: Amount of profit and spent on CSR purpose

\begin{tabular}{|l|l|l|l|l|}
\hline POWER GRID CORPORATION (PGC) (₹ in crore) \\
\hline & $\begin{array}{l}\text { Average profit } \\
\text { Year } \\
\text { before tax of last three } \\
\text { years) }\end{array}$ & $\begin{array}{l}\text { Prescribed CSR } \\
\text { expenditure } \begin{array}{l}\text { (2\% } \\
\text { of the average } \\
\text { profit) } \\
\text { (a) }\end{array}\end{array}$ & $\begin{array}{l}\text { Actual amount } \\
\text { spent } \\
\text { (b) }\end{array}$ & $\begin{array}{l}\text { Unspent(-) } \\
\text { /Overspent(+) } \\
\text { (in rupees) } \\
\text { (b-a) }\end{array}$ \\
\hline $\mathbf{2 0 1 4 - ' 1 5}$ & $5,525.53$ & 110.51 & 47.42 & $(63.09)$ \\
\hline $\mathbf{2 0 1 5 - ' 1 6}$ & $6,089.71$ & 121.79 & 115.78 & $(6.01)$ \\
\hline $\mathbf{2 0 1 6 - ' 1 7}$ & 6,779 & 135.58 & 147.27 & 11.69 \\
\hline $\mathbf{2 0 1 7 - ' 1 8}$ & $7,896.81$ & 157.94 & 157.99 & 0.05 \\
\hline $\mathbf{2 0 1 8 - ' 1 9}$ & $9,336.05$ & 186.72 & 195.52 & 8.8 \\
\hline Total & $\mathbf{2 7 , 7 3 0 . 2 9}$ & $\mathbf{7 1 2 . 5 4}$ & $\mathbf{6 6 3 . 9 8}$ & $\mathbf{4 8 . 5 6 )}$ \\
\hline Mean & $6,932.573$ & 142.508 & 132.796 & $(9.712)$ \\
\hline S.D. & $1,682.307$ & 30.389 & 55.581 & 30.655 \\
\hline C.V & $24.27 \%$ & $21.32 \%$ & $41.85 \%$ & $(315.64) \%$ \\
\hline
\end{tabular}

Source: - Annual Report

From the above table, it can be seen that in the first year the company has spent less than half of the prescribed amount on CSR while the CSR spend for the rest of the years hovers around the prescribed figure. All in all the 
